\title{
PEMANFAATAN EKSTRAK AIR DAUN JAMBU BIJI SEBAGAI ANTIOKSIDAN ALAMI PADA PENGOLAHAN PATIN ASIN
}

\section{The Use of Guava Leaf Water Extract as Natural Antioxidant in The Processing of Dried Salted Catfish}

\author{
Farida Ariyani ${ }^{1 *}$, Jovita Tri Murtini ${ }^{1}$, Gunawan ${ }^{1}$, dan Irma Hermana ${ }^{1}$ \\ ${ }_{1}$ Peneliti pada Balai Besar Penelitian dan Pengembangan Pengolahan Produk dan Bioteknologi Kelautan dan Perikanan, \\ Balitbang KP, KKP \\ * Korespondensi Penulis: JI. K.S. Tubun Petamburan VI, Jakarta Pusat 10260. E-mail: ida_poernomo@yahoo.co.id
}

\begin{abstract}
ABSTRAK
Penelitian pemanfaatan ekstrak air daun jambu biji (Psidium guajava) sebagai antioksidan alami pada pengolahan patin asin telah dilakukan. Aplikasi ekstrak air daun jambu dilakukan dengan merendam ikan dalam campuran larutan garam dan ekstrak daun jambu. Konsentrasi larutan garam yang digunakan adalah $30 \%$, sedangkan variasi konsentrasi ekstrak daun jambu yang digunakan adalah 0,6 , dan $12 \%(\mathrm{w} / \mathrm{v})$. Perendaman dalam larutan garam dilakukan selama 48 jam dengan perbandingan antara ikan dan larutan yang digunakan untuk merendam 1:2 (b/v). Selesai penggaraman, ikan dibelah menjadi bentuk butterfly kemudian dikeringkan di bawah sinar matahari sampai kering (4-5 hari). Pengamatan dilakukan terhadap sifat sensori, kadar air, angka Thio Barbituric Acid (TBA), produk berfluoresen dan proporsi asam lemak tidak jenuh patin asin. Hasil percobaan menunjukkan bahwa penambahan ekstrak air daun jambu pada larutan garam jenuh dengan konsentrasi 6 dan 12\% selama penggaraman mampu menghambat oksidasi lemak patin asin yang tercermin dari penghambatan peningkatan kadar TBA, produk berfluoresen dan penghambatan kerusakan asam lemak tidak jenuh selama penyimpanan 2 bulan. Hasil uji sensori memperlihatkan bahwa patin asin yang diberi perlakuan memberikan bau yang tidak tengik, walaupun warna patin menjadi lebih coklat. Berdasarkan pertimbangan hasil secara kimiawi maupun sensori, perlakuan ekstrak daun jambu pada konsentrasi $6 \%$ merupakan perlakuan terpilih.
\end{abstract}

KATAKUNCl: patin kering asin, ekstrak daun jambu, antioksidan

\section{ABSTRACT}

Research on the use of guava (Psidium guajava) leaf water extract as natural antioxidant in the processing of dried salted catfish was conducted. The application of guava leaf water extract was carried out by immersing fish in the mixture of brine and guava leaf extract. Brine concentration used was $30 \%$, where the solvent consists of guava leaf extract and water with various concentration of guava leaf extract,i.e. 0, 6 and $12 \%(w / v)$. Brining was carried out for $48 \mathrm{~h}$ with proportion of fish and the mixture of brine and guava leaf extract was 1:2 (b/v). After being salted, fish was splitted into butterfly shape and subsequently sun dried for approximately 4-5 days. Observation was performed for sensory characteristics, moisture content, Thio Barbituric Acid (TBA) value, fluorescent products and unsaturated fatty acids proportion of dried salted catfish. The result of the experiment showed that the addition of 6 and $12 \%$ guava leaf water extract on the saturated brine during salting was able to inhibit lipid oxidation of dried salted catfish reflected on the suppressing of TBA value and fluorescent products increasment as well as inhibiting the degradation of unsaturated fatty acids during 2 months storage. Sensory assessment result showed that dried salted catfish treated with guava leaf extract produced unrancid odour, although the colour become brown. Based on the chemical and sensory analysis results, the best treatment was guava leaf extract at concentration of $6 \%$.

KEYWORDS: dried salted catfish, guava leaf extract, antioxidant 


\section{PENDAHULUAN}

Ikan merupakan bahan pangan yang cepat rusak atau mengalami kemunduran mutu. Kerusakan produk perikanan dapat bersifat enzimatis, oksidatif maupun bakteriologis yang akan mengakibatkan terjadinya dekomposisi protein maupun lemak. Kerusakan protein akan mengakibatkan terjadinya kebusukan sedangkan kerusakan lemak akan mengakibatkan terjadinya ketengikan. Ketengikan menyebabkan penurunan kualitas gizi, sensori dan keamanan bahan pangan tersebut yang disebabkan oleh terbentuknya senyawa sekunder yang berpotensi toksik seperti komponen karbonil termasuk acrolein yang erat kaitannya dengan karsinogenesis pada epitel bronchi manusia (Kato et al., 2002; Pak \& Bragadóttir, 2005). Kerusakan lemak banyak terjadi pada produk perikanan olahan akibat penggunaan panas dalam pengolahannya karena kandungan asam lemak tidak jenuh yang cukup tinggi pada lemak produk perikanan. Untuk mengurangi dan menekan terjadinya oksidasi pada produk perikanan, pencarian/eksplorasi bahan alami sebagai antioksidan yang cocok untuk produk perikanan masih perlu dilakukan karena penggunaan antioksidan alami diharapkan menghasilkan produk olahan yang lebih aman baik bagi konsumen maupun lingkungan.

Daun sirih merupakan salah satu bahan alami yang berpotensi sebagai antioksidan dan ekstrak daun sirih mampu menghambat proses oksidasi jambal patin selama penyimpanan, meskipun demikian, jambal patin yang dihasilkan menjadi kecoklatan dan berasa getir (Ariyani et al., 2008). Bahan alami lain yang berpotensi sebagai antioksidan adalah daun jambu biji. Daun jambu biji (Psidium guajava) mengandung senyawa tannin, fenol, flavonoid, kuinon, dan steroid yang mempunyai daya hambat terhadap oksidasi lipid (Qian He, 2004, Hui-Yin \& Gow-Chin. 2007; Stephen, et al., 2009). Pada penelitian sebelumnya, terbukti bahwa penambahan ekstrak daun jambu pada proses perebusan pindang tongkol mampu menghambat proses oksidasi pindang tongkol selama penyimpanan tercermin dari kemampuannya menekan peningkatan angka TBA sebesar 39-59\% (Ariyani et al., 2010). Produk ikan asin berbeda dengan produk pindang, karena dalam proses pengolahannya melalui pengeringan yang pada umumnya dilakukan dengan sinar matahari dan dalam waktu lama, sehingga proses oksidasi pada produk ikan asin diduga lebih cepat dibanding dengan produk pindang.

Ikan patin merupakan salah satu komoditas unggulan ikan air tawar yang mudah dibudidayakan dan mempunyai nilai ekonomis tinggi. Direktorat Jenderal Perikanan Budidaya telah menetapkan ikan patin sebagai salah satu komoditas dari 10 komoditas perikanan unggulan yang berpotensi untuk diekspor (Ditjen Perikanan Budidaya, 2010). Hal ini disebabkan karena patin mempunyai pangsa pasar yang cukup besar baik di dalam maupun di luar negeri dengan nilai jual yang cukup tinggi (Mahyuddin, 2010). Dibandingkan dengan ikan hasil budidaya yang lain, ikan patin mempunyai daging yang relatif tebal sehingga ikan patin sering digunakan sebagai bahan baku dalam pengolahan ikan asin fermentasi (jambal roti) mengingat bahwa bahan baku produk jambal yang biasa digunakan adalah ikan manyung yang semakin terbatas ketersediaannya. Ikan patin mempunyai kadar lemak relatif tinggi dibanding ikan air tawar lain yakni berkisar 1,56-10,0\%. Kadar lemak yang tinggi pada ikan patin ini sering menyebabkan bau tengik pada produk keringnya (patin asin). Dengan demikian diperlukan upaya untuk menekan terjadinya ketengikan pada patin asin.

Pada penelitian ini akan dikaji tingkat efektifitas ekstrak daun jambu biji sebagai antioksidan dalam pengolahan patin asin.

\section{BAHAN DAN METODE}

\section{Bahan}

Bahan baku yang digunakan adalah ikan patin (Pangasius hypophthalmus) hidup yang diperoleh dari pembudidaya ikan patin di Parung, Bogor dengan kisaran bobot badan 640-700 gram dan panjang total total $45-51 \mathrm{~cm}$. Sesampainya di Laboratorium BBP4BKP, ikan dimatikan dengan cara penusukan pada bagian kepala. Daun jambu biji (Psidium guajava) yang sudah tua dan segar dan merupakan daun ke 4-5 dihitung dari pucuk daun yang diperoleh dari Balai Tanaman Rempah dan Obat di Bogor; untuk selanjutnya hanya disebut sebagai daun jambu, sedangkan garam yang digunakan adalah garam kristal (krosok) ukuran sedang yang diperoleh dari pasar Palmerah.

\section{Metode}

\section{Ekstrak daun jambu}

Daun jambu dicuci terlebih dahulu untuk menghilangkan kotoran yang menempel. Ekstraksi dilakukan dengan merebus daun jambu dalam air dengan perbandingan daun jambu : air $=1: 4(\mathrm{~b} / \mathrm{v})$ selama 4 jam. Setelah mencapai 4 jam, campuran daun jambu dan air didinginkan pada suhu ruang dan disaring dengan kain nilon. Ampas daun jambu tersebut kemudian dibilas dengan air panas, disaring dan hasil penyaringan ke dua ditambahkan ke dalam ekstrak 
hasil penyaringan pertama hingga mencapai volume semula dan digunakan sebagai ekstrak induk. Ekstrak ini kemudian disimpan dalam jerigen berwarna gelap dan disimpan pada suhu $4^{\circ} \mathrm{C}$ sampai siap digunakan.

\section{Aplikasi ekstrak daun jambu pada pengolahan patin asin}

Pembuatan patin asin dilakukan menurut metode yang digunakan Nasran et al. (1995) dengan modifikasi. Ikan patin segar disiangi (dibuang kepala dan isi perut), dicuci, ditiriskan. Ikan kemudian ditempatkan dalam bak plastik dan dibiarkan pada suhu ruang selama 6 jam (autolisis) untuk memfasilitasi proses enzimatis selama fase rigor mortis sehingga diharapkan dapat memperoleh tekstur patin asin yang empuk.

Ikan selanjutnya direndam dalam larutan garam $30 \%$ yang mengandung ekstrak daun jambu dengan konsentrasi 0,6 , dan $12 \%$. Konsentrasi ekstrak daun jambu tersebut dipilih berdasarkan penelitian pendahuluan dan diperoleh dari pengenceran ekstrak induk. Penggaraman dilakukan selama 48 jam dengan perbandingan antara ikan dan larutan yang digunakan untuk merendam yaitu 1:2 (b/v). Selanjutnya ikan dicuci, ditiriskan dan dibelah sehingga berbentuk butterfly. Patin yang telah berbentuk butterfly kemudian dikeringkan di bawah sinar matahari sampai kering komersial, kemudian dikemas dalam kantong plastik PE dan disimpan pada suhu ruang $(26,5-$ $\left.28,5^{\circ} \mathrm{C}\right)$.

\section{Pengamatan}

Pengamatan dilakukan terhadap sifat sensoris patin asin, kadar air, TBA dan produk berfluoresen, sedangkan analisis asam lemak dilakukan pada sampel dengan perlakuan terbaik.

Penilaian sifat organoleptik pindang dilakukan dengan menggunakan lembar penilaian 5 tingkat untuk atribut warna, bau tengik, bau ketajaman daun, dan rasa oleh 7 panelis terlatih. Analisis kadar air dilakukan berdasarkan metode AOAC (1999), penentuan angka TBA dilakukan menurut metode Ramanathan \& Das (1992), dan profil asam lemak menurut metode AOAC (1993) menggunakan Gas Chromatography dengan kolom cyanopropyl methyl sil berukuran $60 \mathrm{~m} \times 0,25$ $\mathrm{mm} \times 0,25 \mathrm{ì} \mathrm{m}$. Suhu detector $230^{\circ} \mathrm{C}$, suhu injector $200^{\circ} \mathrm{C}$ dengan system split (ratio 8:1) dan oven program $190^{\circ} \mathrm{C}$ dengan kenaikan $10^{\circ} \mathrm{C} /$ menit sampai $230^{\circ} \mathrm{C}$ menggunakan gas hydrogen dengan kecepatan alir $30 \mathrm{~mL} /$ menit. Internal standar yang digunakan adalah tricosan (C23:0).

Percobaan dirancang menggunakan rancangan acak lengkap faktorial dengan 2 perlakuan yaitu perbandingan konsentrasi ekstrak daun jambu dan lama penyimpanan dengan 3 ulangan.

\section{HASIL DAN BAHASAN}

\section{Perubahan Sifat Kimia}

Gambar 1-5 memperlihatkan terjadinya perubahan kadar air, TBA, produk berfluoresen, asam lemak maupun asam lemak omega-3 patin asin selama penyimpanan pada suhu ruang.

\section{Kadar air (\%)}

Kadar air patin asin kontrol maupun patin asin dengan perlakuan ekstrak daun jambu relatif konstan

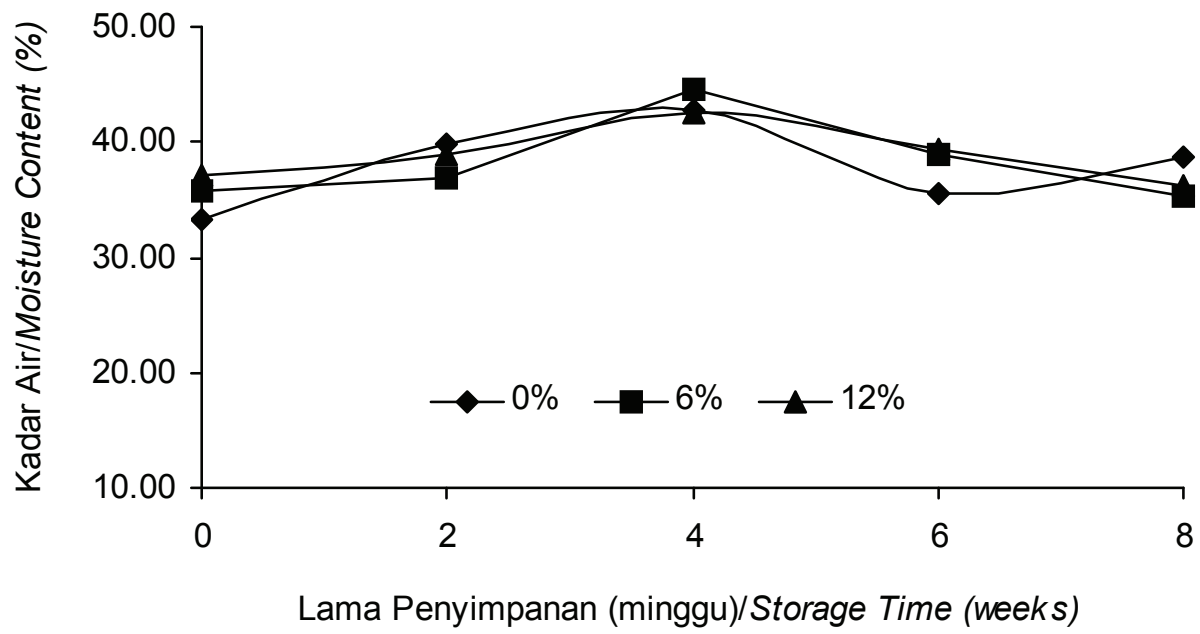

Gambar 1. Perubahan nilai kadar air patin asin dengan perlakuan ekstrak daun jambu biji selama penyimpanan pada suhu ruang.

Figure 1. The changes of moisture content of dried salted catfish treated with guava leave extract during storage at ambient temperature. 
selama penyimpanan kecuali pada hari ke-4 penyimpanan terjadi peningkatan kadar air pada semua patin asin (Gambar 1). Peningkatan kadar air ini disebabkan terjadinya peningkatan kelembaban ruang penyimpanan yaitu sebesar $87 \%$, sedangkan pada titik pengamatan lain kelembaban berkisar 69$72 \%$. Kisaran kadar air patin asin pada penelitian ini adalah 33,4-44,6\% yang tidak jauh berbeda dengan kadar air patin asin pada perlakuan ekstrak bawang putih sebagai pengawet yaitu 32,9-41, 7 (Ariyani et al., 2009).

\section{Angka TBA (i Mol MDA/kg)}

Hasil pengukuran terhadap angka TBA sebagai salah satu parameter indikator terjadinya oksidasi menunjukkan bahwa patin asin dengan perlakuan ekstrak daun jambu mempunyai angka TBA yang lebih rendah secara nyata $(P<0,05)$ dibanding patin asin kontrol, sedangkan antar perlakuan (konsentrasi ekstrak daun jambu 6 dan 12\%) tidak memberikan perbedaan nyata pada angka TBA (Gambar 2). Komponen polifenol dan flavonoid yang terdapat pada ekstrak daun jambu diduga bertanggung jawab dalam penghambatan proses oksidasi pada patin asin (Qian $\mathrm{He}, 2004)$. Pada penelitian sebelumnya, ekstrak daun jambu dengan konsentrasi 6-9\% yang diaplikasikan pada produk patin lain (pindang patin) selama 2 hari penyimpanan pada suhu ruang mampu menghambat kenaikan angka TBA sebesar 39-59\% (Ariyani et al., 2010), sedangkan pada penelitian ini ekstrak daun jambu pada konsentrasi 6 dan 12\% mampu menekan peningkatan angka TBA sebesar $31-39 \%$ pada penyimpanan 8 minggu. Dibandingkan dengan ekstrak bahan alami yang dilakukan pada penelitian sebelumnya, ekstrak bawang putih pada konsentrasi yang sama ( $9 \%)$, mampu menekan peningkatan nilai TBA jambal patin sebesar 60,2-80,6\% pada kondisi dan waktu penyimpanan yang sama (Ariyani et al., 2009), sedangkan ekstrak daun sirih 3,7\% yang diaplikasikan pada jambal patin selama penggaraman mampu menekan kenaikan nilai TBA jambal patin sebesar $58 \%$ pada penyimpanan 4 minggu pada suhu ruang (Ariyani et al., 2008). Dengan demikian dapat diperkirakan bahwa kemampuan daya hambat ekstrak daun jambu terhadap proses oksidasi masih di bawah kemampuan ekstrak bawang putih maupun ekstrak daun sirih.

Mengacu kepada batasan bahwa ikan dengan kadar TBA > 10 ì Mol MDA/kg daging dianggap tengik (Ke \& Ackman, 1976), maka jambal patin kontrol mulai tengik pada penyimpanan minggu ke-4, sedangkan jambal patin dengan perlakuan penambahan ekstrak daun jambu pada 6 dan 12\% belum tengik sampai akhir penyimpanan (8 minggu). Penurunan angka TBA yang terjadi pada patin asin kontrol setelah 4 minggu penyimpanan, bukan berarti bahwa produk tidak tengik atau tidak teroksidasi, tetapi hal ini kemungkinan disebabkan oleh adanya reaksi antara malonaldehid hasil oksidasi dengan gugus amino pada daging yang membentuk struktur 1-amino-3-aminopropene (Shahidi, 1998). Fenomena yang sama juga terjadi pada penelitian pengasapan ikan mullet ( $V$. seheli) yaitu angka TBA ikan $V$. seheli asap 3,96 $\pm 0,12 \mathrm{mg}$ $\mathrm{MDA} / \mathrm{kg}$ pada hari ke 4, turun menjadi 3,74 $\pm 0,03 \mathrm{mg}$ $\mathrm{MDA} / \mathrm{kg}$ pada hari ke 8 kemudian turun lagi menjadi $0,12 \pm 0,04 \mathrm{mg} \mathrm{MDA} / \mathrm{kg}$ sesudah 19 hari penyimpanan (Oduor-Odote \& Obiero, 2009). Untuk mengkonfirmasi kemampuan ekstrak daun jambu dalam menekan

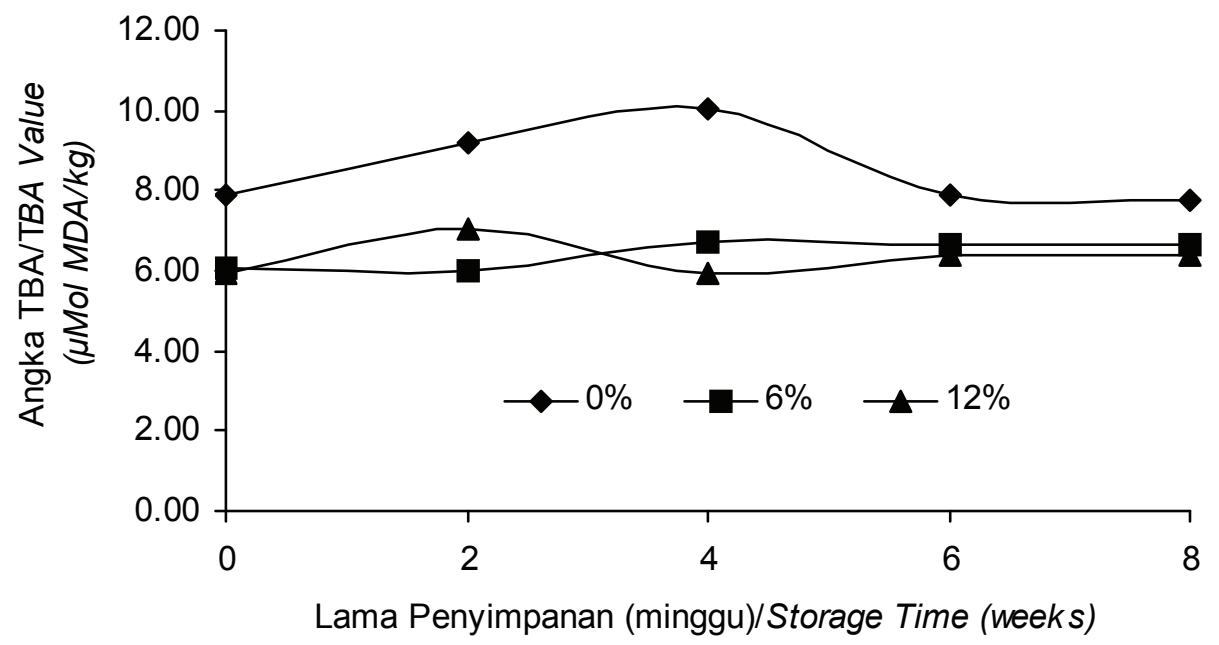

Gambar 2. Perubahan angka TBA patin asin dengan perlakuan ekstrak daun jambu biji selama penyimpanan pada suhu ruang

Figure 2. The changes of TBA value of dried salted catfish treated with guava leave extract during storage at ambient temperature 
proses oksidasi pada pengolahan patin asin, selain TBA, juga dilakukan analisis pada parameter oksidasi lain yaitu produk berfluoresen dan profil asam lemak.

\section{Produk berfluoresen (i g/100 g ikan)}

Perubahan produk berfluoresen patin asin selama penyimpanan pada suhu ruang disajikan pada Gambar 3.

Metode analisis produk berfluoresen merupakan metoda analisis yang dinilai mempunyai ketepatan yang tinggi dalam mendeteksi proses oksidasi dalam produk pangan terutama ikan (Fletcher et al., 1973; Lubis 1989; Ariyani, 1998; Aubourg, 2000; Shahidi \& Zhong, 2005; Sádecká \& Tóthová, 2007).

Dari hasil penelitian terlihat bahwa selama penyimpanan, angka produk berfluoresen lebih rendah secara nyata pada patin asin dengan perlakuan ekstrak daun jambu 6 dan $12 \%$ dibanding patin asin kontrol $(P<0,05)$, sedangkan antar konsentrasi ekstrak daun jambu yang ditambahkan tidak berbeda nyata $(P>0,05)$ (Gambar 3). Pola perubahan produk berfluoresen pada patin asin selama penyimpanan sedikit berbeda dengan pola perubahan angka TBA, yaitu selalu meningkat dengan bertambahnya waktu penyimpanan, sementara angka TBA mengalami penurunan setelah penyimpanan 6 hari pada kontrol dan konstan pada patin asin dengan perlakuan ekstrak daun jambu. Hal ini disebabkan produk berfluoresen merupakan senyawa hasil reaksi antara hasil oksidasi termasuk TBA dengan protein, asam amino. maupun DNA yang mengandung gugus amino (Shahidi \&
Zhong, 2005) sehingga apabila terjadi penurunan angka TBA sementara proses oksidasi masih berlangsung, angka produk berfluoresen justru naik. Hal ini mendukung pernyataan Sivertsen et al. (2006), bahwa tidak terjadi korelasi linier antara angka TBA dengan spectrum fluorescent pada ikan karang dari saithe (Pollachius virens). Oleh karena itu, parameter produk berfluoresen dinilai merupakan parameter oksidasi yang lebih akurat terutama untuk produk pangan yang mudah teroksidasi dan mengandung protein tinggi seperti produk perikanan.

Meningkatnya angka produk berfluoresen selama penyimpanan mengindikasikan bahwa dengan bertambahnya lama penyimpanan, semakin besar tingkat oksidasi lemak yang terjadi. Pada penelitian ini kenaikan tingkat oksidasi patin asin dengan berbagai perlakuan tercermin dari kenaikan angka produk berfluoresen sebesar $65,52-80,65 \%$ pada 2 minggu penyimpanan dan $73,73-83,34 \%$ pada penyimpanan 8 minggu. Pola serupa terjadi pada penyimpanan patin asin dengan perlakuan ekstrak sirih, yang menunjukkan bahwa kenaikan angka produk berfluoresen patin asin pada penyimpanan 2 minggu dan 8 minggu berturut-turut sebesar 70,32$84,80 \%$ dan 90,20-93,69\% (Ariyani et al., 2008). Demikian juga pada penyimpanan sardine asin selama 6 minggu terjadi kenaikan angka produk berfluoresen sebesar 73,52\% (Lubis, 1989). Hal ini mendukung pernyataan Hasegawa et al. (1992) bahwa produk berfluoresen mempunyai korelasi positif yang tinggi dengan jumlah oksigen terabsorbsi selama proses oksidasi pada ikan kering sedangkan Chotimarkorn

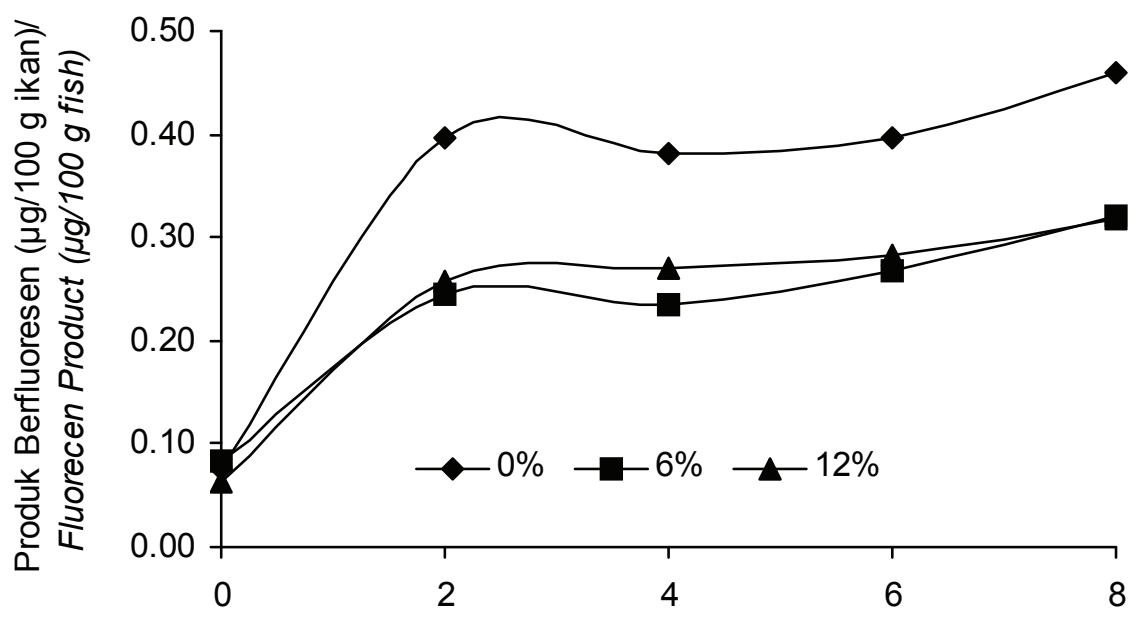

Lama Penyimpanan (minggu)/Storage Time (weeks)

Gambar 3. Nilai Produk berfluoresen patin asin dengan perlakuan ekstrak daun jambu biji selama penyimpanan pada suhu ruang.

Figure 3. Fluorescent products of dried salted catfish treated with guava leave extract during storage at ambient temperature. 
et al. (2006) menyatakan bahwa produk berfluoresen berkorelasi positif dengan hidroperoksida total pada ekstrak daging ikan.

\section{Asam lemak (\%)}

Dilihat dari hasil analisis parameter oksidasi TBA, produk berfluoresen, dan nilai sensori untuk atribut bau daun dan rasa yang tidak memberikan perbedaan nyata pada ekstrak daun jambu 6 dan 12\%, juga mempertimbangkan hasil analisis atribut warna pada perlakuan $12 \%$ yang memberikan nilai terendah, maka dalam analisis lebih lanjut untuk melihat komponen asam lemak hanya dilakukan pada kontrol $(0 \%)$ dan perlakuan ekstrak daun jambu dengan konsentrasi $6 \%$ pada akhir penyimpanan (8 minggu).

Berdasarkan hasil analisis komponen asam lemak, terlihat bahwa penambahan ekstrak daun jambu pada konsentrasi $6 \%$ mampu menekan tejadinya oksidasi pada asam lemak dengan ikatan rangkap lebih dari satu (Gambar 4). Apabila semua asam lemak dengan ikatan rangkap 1, 2, 3, 4, 5, dan 6 dijumlahkan, maka setelah penyimpanan 8 minggu patin asin kontrol mempunyai jumlah asam lemak tidak jenuh $32,95 \%$ wb, sedangkan jumlah asam lemak tidak jenuh patin asin dengan perlakuan ekstrak daun jambu adalah $42,68 \%$ wb. Dengan demikian penghambatan laju oksidasi asam lemak tidak jenuh karena penambahan ekstrak daun jambu sebesar $22,80 \%$ dengan persen penghambatan tertinggi pada ikatan rangkap lebih dari 4.

Pada produk pindang patin, penghambatan laju oksidasi asam lemak tidak jenuh karena penambahan ekstrak daun jambu 9\% lebih rendah, yaitu sebesar $14,7 \%$ yang terhitung dari $42,95 \%$ wb pada pindang patin kontrol selama penyimpanan 3 hari dan $50,39 \%$ wb pada pindang patin dengan perlakuan ekstrak daun jambu pada penyimpanan yang sama (Ariyani et al., 2010).

Rendahnya nilai penghambatan kerusakan asam lemak tidak jenuh pada pindang patin bila dibandingkan dengan patin asin kemungkinan disebabkan karena laju oksidasi pada pindang patin tidak secepat laju oksidasi pada patin asin. Hal ini terefleksi dari persentase asam lemak tidak jenuh pada pindang patin yang lebih tinggi, yakni kontrol 42,95\% (bb) dan ekstrak daun jambu 50,39\% wb (Ariyani et al., 2010), dibanding patin asin pada penelitian ini, baik untuk kontrol $(32,95 \% \mathrm{wb})$ maupun patin dengan perlakuan ekstrak daun jambu $(42,68 \%$ bb). Pengeringan menggunakan sinar matahari dalam waktu yang relatif lama (4 hari) pada pembuatan patin asin, menjadi salah satu penyebab kerusakan asam lemak tidak jenuh yang relatif tinggi, karena peningkatan pemaparan oleh sinar dan suhu tinggi menyebabkan peningkatan penyerapan oksigen pada sistem yang mengandung Poly Unsaturated Fatty Acids (PUFA) (Davis et al., 1993) sehingga mempercepat proses autoksidasi. Lebih jauh dinyatakan bahwa sinar ultraviolet merupakan penyedia sumber energi yang dibutuhkan untuk proses inisiasi dan propagasi pada proses oksidasi lemak (Tatum \& Chow, 1992). Energi UV yang terabsorbsi kemudian memproduksi oksigen singlet $\left({ }^{1} \mathrm{O}_{2}\right)$ yang sangat reaktif yang kemudian bereaksi dengan asam lemak tidak jenuh karena adanya ikatan rangkap dengan densitas elektron yang sangat tinggi untuk memproduksi peroksi radikal dan hidroperoksida. Kecepatan reaksi foto oksidasi ini jauh lebih tinggi dibandingkan dengan kecepatan autoksidasi

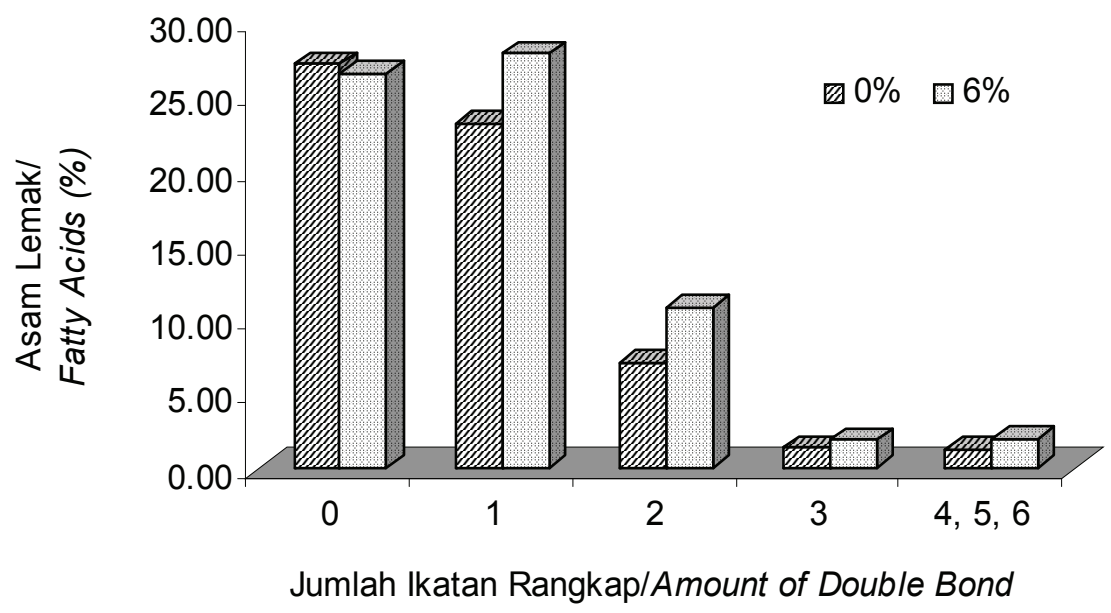

Gambar 4. Persentasi asam lemak patin asin dengan perlakuan ekstrak daun jambu biji setelah 8 minggu penyimpanan pada suhu ruang.

Figure 4. Fatty acids percentage of dried salted catfish treated with guava leave extract after 8 weeks of storage at ambient temperature. 
(Indrasena \& Barrow 2011). Pengeringan menggunakan sinar radiasi gelombang mikro pada daging lumat ikan mas dan makarel setelah penyimpanan pada suhu dingin juga telah menurunkan jumlah asam lemak tidak jenuh secara nyata (Mahmoed et al., 2009).

Penyimpanan pada suhu kamar $\left(26,5-28,5^{\circ} \mathrm{C}\right)$ yang relatif lama ( 8 minggu) diduga juga berkontribusi terhadap penurunan asam lemak tidak jenuh pada patin asin. Kandungan asam lemak berantai panjang dengan banyak ikatan rangkap menjadi pemicu terjadinya oksidasi lemak. Komponen PUFA yang cukup tinggi pada lemak ikan sangat sensitif terhadap kerusakan yang disebabkan proses oksidasi.

Berdasarkan jumlah asam lemak omega-3, penambahan ekstrak daun jambu 6\% mampu menekan terjadinya oksidasi asam lemak omega 3 (Gambar 5). Pada patin asin kontrol, jumlah asam lemak omega 3 yang terdiri atas C18:2 (asam linolenat), C20:3 (asam eikosatrienoat), C20:5 (eikosapentaenoat) dan C22:6 (dokosaheksaenoat) adalah $0,98 \% \mathrm{wb}$, sedangkan jumlah asam lemak omega 3 patin asin dengan perlakuan ekstrak daun jambu sebesar $1,42 \% \mathrm{wb}$, sehingga penghambatan laju oksidasi asam lemak omega-3 karena penambahan ekstrak daun jambu sebesar 31,38\%.

Penghambatan ekstrak daun jambu terhadap proses oksidasi terjadi melalui mekanisme penghambatan radikal bebas (free radical scavenging) yang berakibat pada penurunan senyawa produk oksidasi sekunder (Tachakittirungrod et al., 2007), sedangkan Hui-Yin \& Gow-Chin (2007) menyatakan bahwa terdapat korelasi linier antara potensi antioksidan dan kemampuan menghambat pembentukan radikal bebas dengan kadar fenol dari ekstrak daun jambu. Penurunan jumlah asam lemak omega 3 selama 8 minggu penyimpanan disebabkan karena proses auto oksidasi yang berlangsung pada suhu ruang dengan ketersediaan oksigen di atmosfir, sementara penyimpanan ikan pada suhu bekupun masih dapat menurunkan jumlah asam lemak tidak jenuh pada beberapa jenis ikan (Pirestani et al., 2010) dan asam lemak omega 3 sebesar $48 \%$ pada ikan mackerel (Scomberomorus commersoni) dan $42,83 \%$ pada ikan cucut (Carcharhinus dussumieri) (Nazemroaya et al., 2011).

\section{Perubahan Karakteristik Sensori}

Hasil analisis data dari uji sensori disajikan pada Gambar 6-10.

Berdasarkan hasil analisis sensori yang dilakukan oleh panelis pada sampel dengan penyimpanan selama 8 minggu, terlihat bahwa penambahan ekstrak daun jambu memberikan nilai penerimaan terhadap warna yang lebih rendah secara nyata $(P<0,05)$ dibanding kontrol (Gambar 6). Warna pada patin kontrol adalah kuning kecoklatan, sedangkan warna patin asin dengan penambahan ekstrak daun jambu adalah coklat muda - coklat kehitaman dan semakin tinggi konsentrasi ekstrak daun jambu dalam larutan garam memberikan warna patin asin yang semakin tua.

Senyawa polifenol yang terdapat pada daun jambu (Qian He, 2004; Stephen et al., 2009) dimungkinkan sebagai penyebab timbulnya warna gelap pada patin asin dengan perlakuan ekstrak daun jambu. Menurut Haard \& Chrism (1994), komponen fenolik ini akan teroksidasi dan berkondensasi lebih lanjut

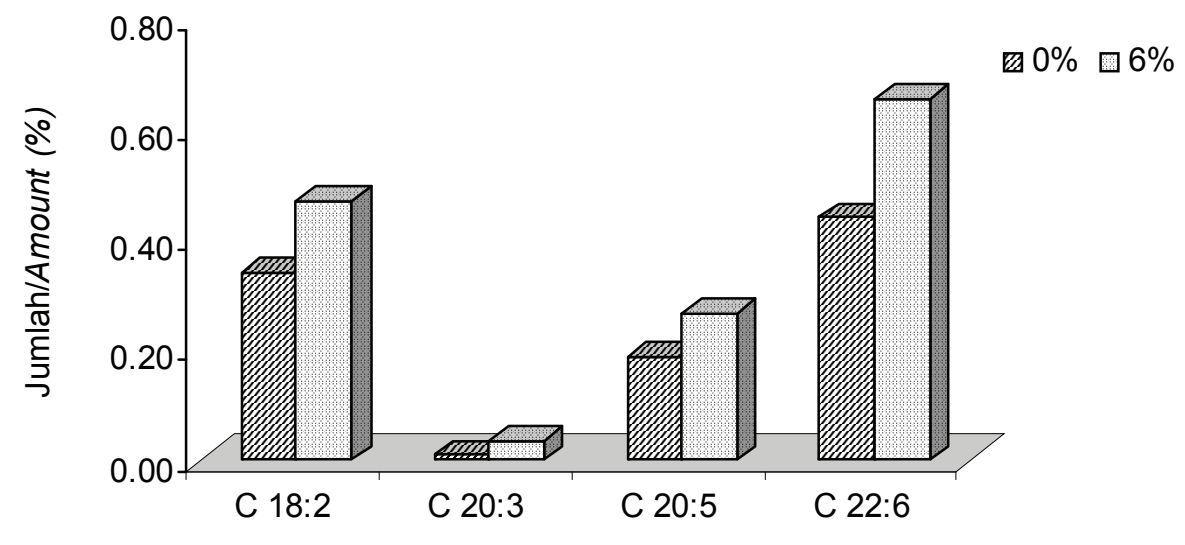

Asam Lemak Omega-3/Omega-3 Fatty Acids

Gambar 5. Persentasi asam lemak omega 3 patin asin dengan perlakuan ekstrak daun jambu biji setelah 8 minggu penyimpanan pada suhu ruang

Figure 5. Omega-3 fatty acids percentage of dried salted catfish treated with guava leave extract after 8 weeks of storage at ambient temperature 


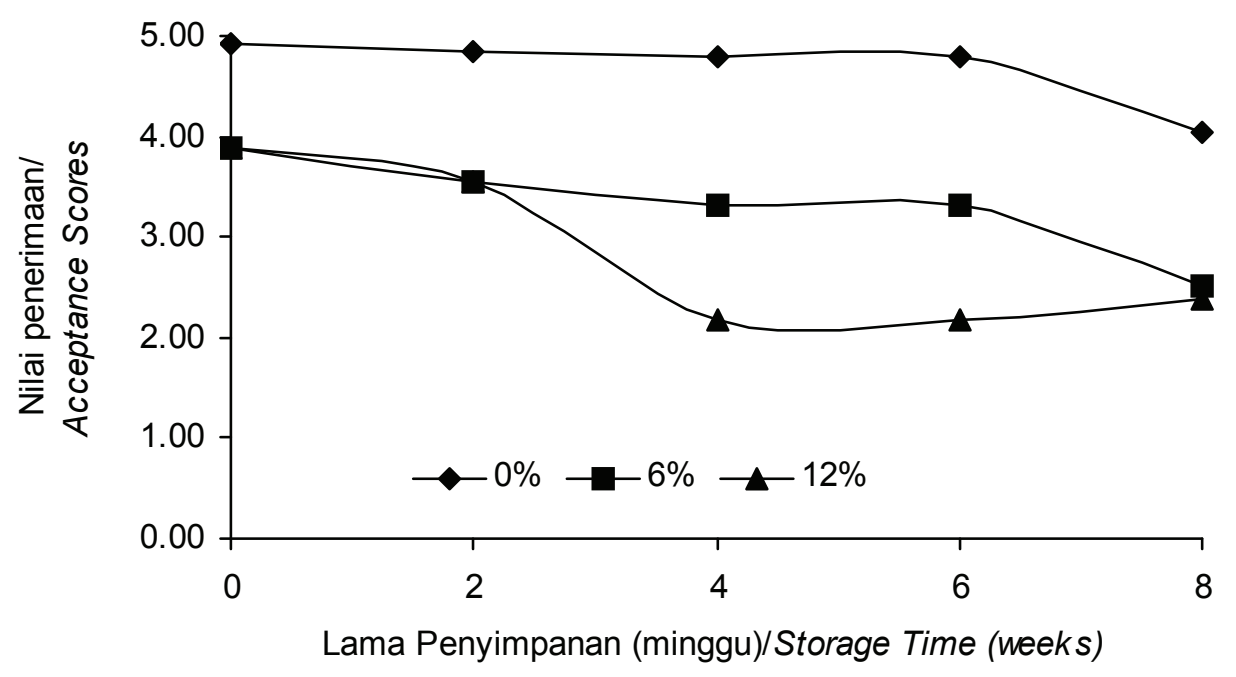

Gambar 6. Perubahan nilai penerimaan terhadap warna patin asin dengan perlakuan ekstrak daun jambu biji selama penyimpanan pada suhu ruang

Figure 6. The changes of color acceptance score of dried salted catfish treated with guava leave extract during storage at ambient temperature

menghasilkan komponen dengan berat molekul tinggi yang berwarna coklat.

Sampai dengan penyimpanan 6 minggu, nilai penerimaan terhadap atribut patin asin kontrol maupun patin asin dengan penambahan ekstrak daun jambu $6 \%$ sedikit menurun, tetapi pada akhir penyimpanan (8 minggu), nilai penerimaan tersebut terlihat menurun secara nyata dan telah melewati nilai batas penerimaan (nilai batas $=3$ ) untuk patin asin dengan perlakuan ekstrak daun jambu $6 \%$. Sedangkan penurunan nilai penerimaan atribut warna patin asin dengan penambahan ekstrak daun jambu $12 \%$ telah terlihat nyata dan melewati batas penerimaan sejak penyimpanan 4 minggu, kemudian terlihat konstan sampai akhir penyimpanan. Ketersediaan oksigen di atmosfir dan suhu ruang penyimpanan yang relatif tinggi $\left(26,5-28,5^{\circ} \mathrm{C}\right)$ menjadi penyebab terjadinya proses oksidasi lemak patin asin selama penyimpanan (Pokorny et al., 2001).

Pada Gambar 7 terlihat bahwa bau tengik pada perlakuan kontrol terdeteksi lebih kuat dibanding dengan patin asin dengan perlakuan ekstrak daun jambu sehingga nilai yang diberikan panelis pada bau tengik patin asin kontrol lebih rendah dari nilai patin

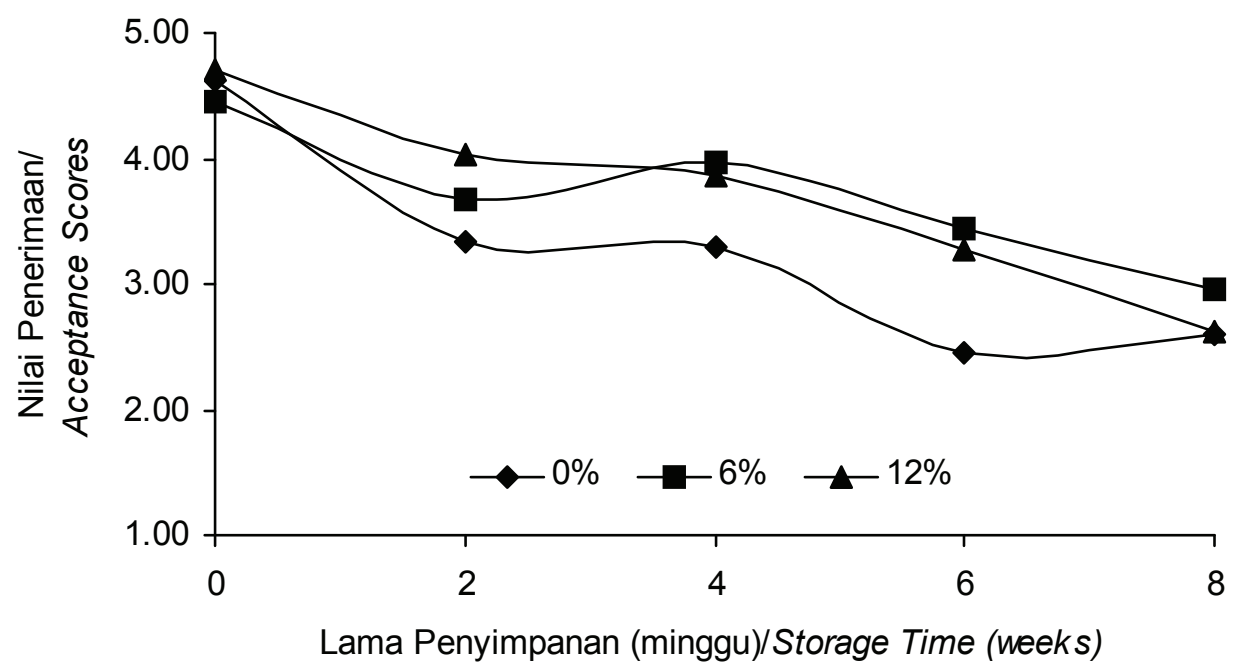

Gambar 7. Perubahan nilai penerimaan terhadap bau tengik patin asin dengan perlakuan ekstrak daun jambu biji selama penyimpanan pada suhu ruang

Figure 7. The changes of rancidity acceptance score of dried salted catfish treated with guava leave extract during storage at ambient temperature 
asin dengan perlakuan ekstrak daun jambu. Hasil uji atribut bau menunjukkan bahwa patin asin kontrol mempunyai bau yang lebih tengik dibandingkan patin asin yang diberi perlakuan ekstrak daun jambu. Berbeda dengan atribut warna, hasil uji atribut bau selama penyimpanan memperlihatkan bahwa intensitas ketengikan patin asin kontrol dan patin asin dengan penambahan ekstrak daun jambu semakin tinggi dengan semakin lama penyimpanan, sehingga nilai penerimaan terhadap bau tengik semakin menurun (Gambar 7). Nilai penerimaan terhadap bau tengik patin kontrol telah di bawah nilai 3 yang merupakan batas penerimaan pada penyimpanan 4 minggu, sedangkan nilai penerimaan terhadap bau tengik patin asin dengan perlakuan ekstrak daun jambu 6 dan 12\% melewati batas penerimaan pada penyimpanan 8 minggu.

Bau daun jambu pada patin kontrol tidak terdeteksi dengan nilai penerimaan 4,8-5,0, sedangkan pada patin asin dengan semua penambahan daun jambu terdeteksi lemah dengan nilai penerimaan 4,5-4,8 (Gambar 8). Hal ini memberikan nilai positif pada ekstrak daun jambu karena aroma daun jambu tidak mengganggu karakteristik aroma patin asin pada

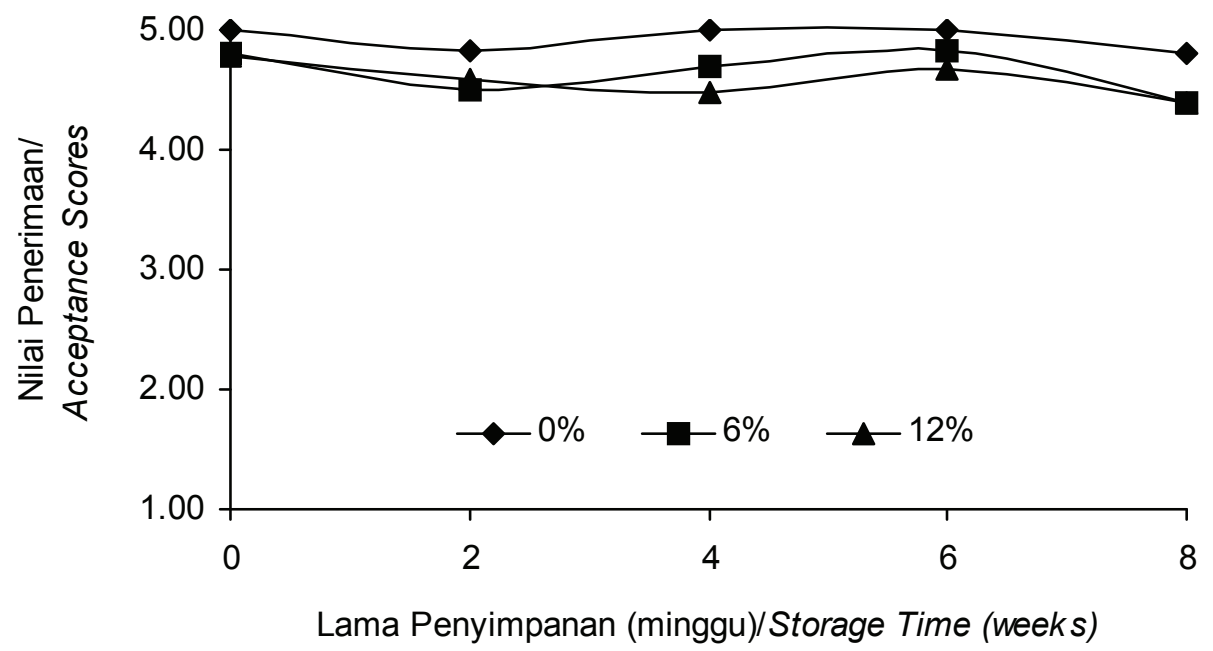

Gambar 8. Perubahan nilai penerimaan terhadap bau daun pada patin asin dengan perlakuan ekstrak daun jambu biji selama penyimpanan pada suhu ruang.

Figure 8. The changes of leave aroma acceptance score of dried salted catfish treated with guava leave extract during storage at ambient temperature.

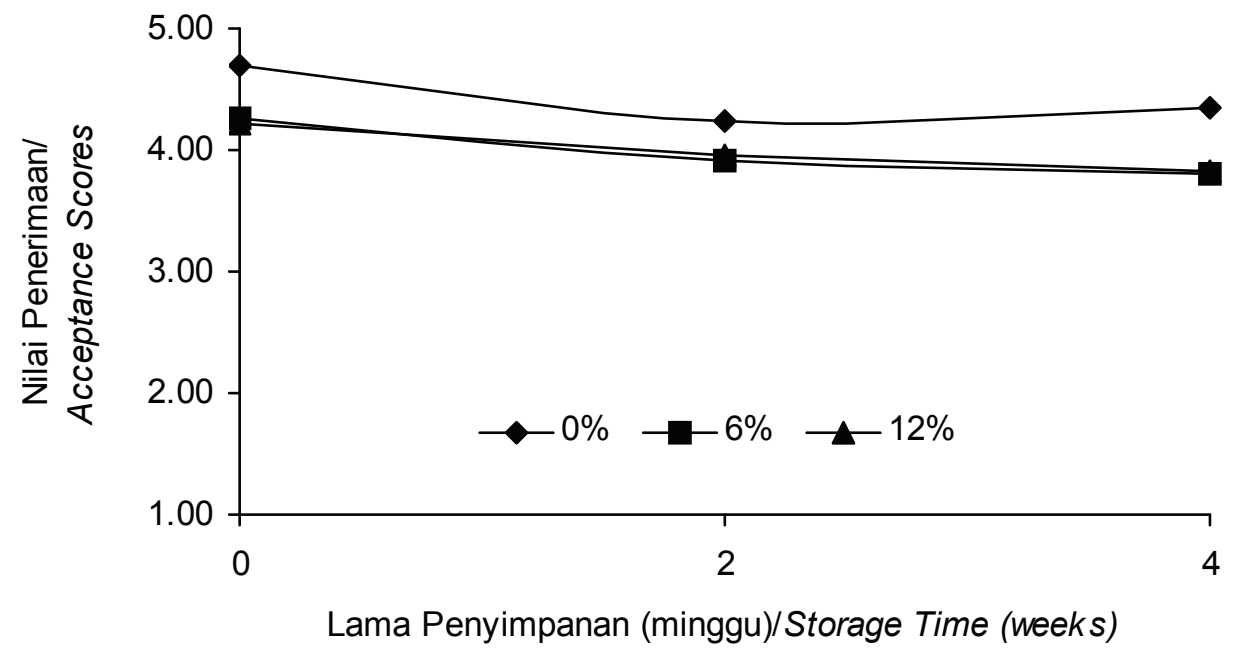

Gambar 9. Perubahan nilai penerimaan terhadap rasa patin asin dengan perlakuan ekstrak daun jambu biji selama penyimpanan pada suhu ruang

Figure 9. The changes of taste acceptance score of dried salted catfish treated with guava leave extract during storage at ambient temperature 
penelitian ini dan berbeda dengan ekstrak daun sirih yang meninggalkan aroma daun yang kuat pada produk akhirnya (Ariyani et al., 2008).

Asesmen terhadap atribut rasa patin asin pada penelitian ini hanya dilakukan sampai dengan penyimpanan minggu ke-4 (Gambar 9) karena mulai minggu ke-6 penyimpanan, sebagian produk mulai berjamur, meskipun nilai penerimaan atribut yang lain (warna, bau tengik dan bau daun) pada penyimpanan 6 minggu masih di atas batas penerimaan (batas penerimaan=3) dan belum ditolak. Pada penyimpanan 4 minggu, atribut rasa patin asin dengan perlakuan ekstrak daun jambu sedikit lebih rendah dibanding dengan patin asin kontrol, tetapi nilai penerimaan masih cukup tinggi yaitu 3,8 (tidak sepet/tidak pahit).

Gambaran secara umum menunjukkan bahwa patin asin dengan perlakuan ekstrak daun jambu maupun kontrol disukai panelis dengan tingkat kesukaan yang hampir tidak berbeda (Gambar 10). Sampai dengan penyimpanan minggu ke-4 nilai kesukaan masih relatif tinggi yakni kontrol 5,1 sedangkan patin dengan perlakuan ekstrak daun jambu 4,5-4,8. Turunnya nilai kesukaan setelah penyimpanan 6 hari lebih disebabkan karena munculnya jamur pada permukaan kulit sebagian patin asin.

Berdasarkan hasil analisis sensori terlihat bahwa penambahan ekstrak daun jambu telah meningkatkan nilai penerimaan terhadap bau tengik dibanding kontrol, sementara untuk atribut warna, patin asin kontrol masih jauh lebih unggul dibanding patin asin dengan penambahan ekstrak daun jambu khususnya pada konsentrasi ekstrak $12 \%$. Demikian juga dengan atribut bau daun maupun atribut rasa patin asin masih sedikit di bawah nilai kontrol. Meskipun demikian nilai atribut bau daun jambu dan rasa patin masih di atas nilai batas penerimaan berturut-turut yaitu 4,4 dan 3,8 (nilai batas penerimaan 3 ). Hal ini masih memberikan nilai positif dalam aplikasi bahan alami sebagai pengawet, karena selama ini pengaruh bau dan rasa bahan alami yang melekat sangat kuat pada produk akhir dan mengubah karakteristik produk akhirnya menjadi kendala yang tidak mudah untuk ditanggulangi.

Dilihat dari aspek kimiawi, semua nilai parameter oksidasi (TBA, produk berfluoresen, asam lemak tidak jenuh dan asam lemak omega-3) patin asin dengan perlakuan ekstrak daun jambu memperlihatkan penghambatan proses oksidasi secara nyata dibanding kontrol.

Dalam eksplorasi bahan alami sebagai pengawet, pemilihan didasarkan pada efektifitas bahan tersebut tanpa menghilangkan karakteristik dasar produk akhir dan masih diterima secara sensori. Dengan demikian dapat dikatakan bahwa perlakuan ekstrak daun jambu pada pengolahan patin asin telah mampu menekan proses oksidasi pada patin asin dan secara sensori masih diterima.

\section{KESIMPULAN}

Penambahan ekstrak daun jambu dengan konsentrasi 6 dan $12 \%$ pada larutan garam jenuh selama penggaraman mampu menghambat oksidasi lemak patin asin yang tercermin dari penghambatan peningkatan kadar TBA dan produk berfluoresen serta

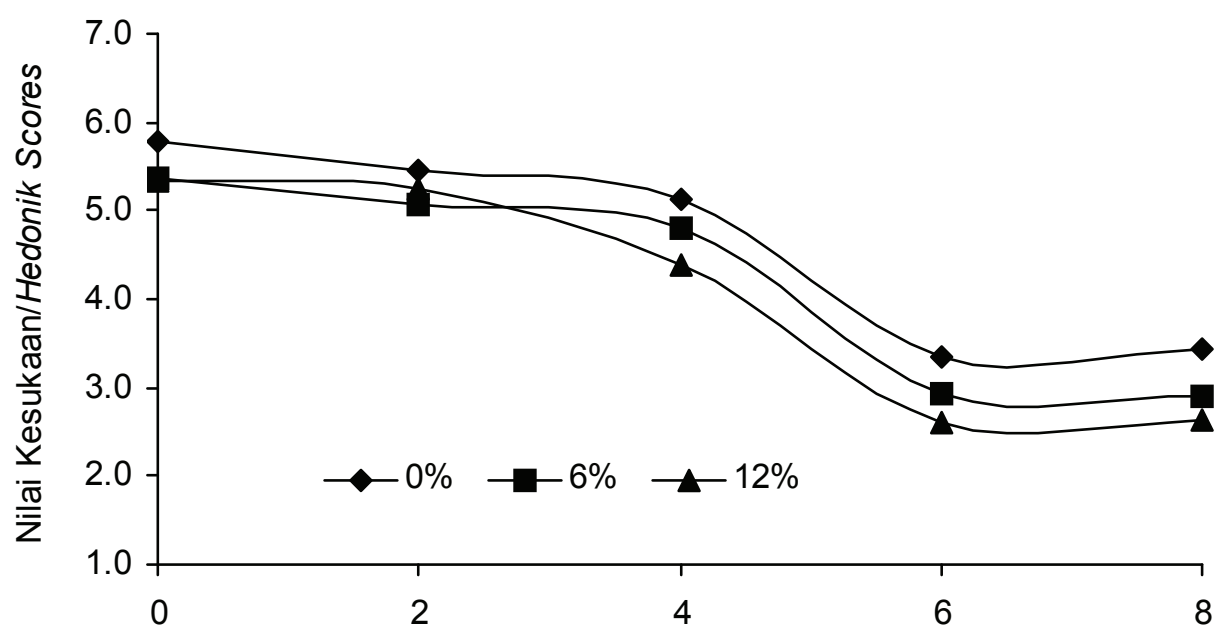

Lama Penyimpanan (minggu)/Storage Time (weeks)

Gambar 10. Perubahan tingkat kesukaan patin asin dengan perlakuan ekstrak daun jambu biji selama penyimpanan pada suhu ruang.

Figure 10. The changes of hedonic score of dried salted catfish treated with guava leave extract during storage at ambient temperature. 
penghambatan kerusakan asam lemak tidak jenuh selama penyimpanan 8 minggu, sedangkan dari aspek sensori patin asin yang diberi ekstrak air daun jambu mempunyai bau yang tidak tengik, meskipun warna patin asin menjadi kecoklatan.

Berdasarkan pertimbangan hasil secara kimiawi maupun sensori, perlakuan ekstrak daun jambu pada konsentrasi $6 \%$ merupakan perlakuan terpilih.

\section{DAFTAR PUSTAKA}

AOAC, 1993. Official Methods of Analysis, C.E. 2-66. Preparation of Methyl Ester of Longchain Fatty Acids Animal. Association of Official Analytical Chemists. Washington, D.C.

AOAC. 1999. Official Methods of Analysis, 13th ed. Method no. 24.046. Association of Official Analytical Chemists. Washington, D.C.

Ariyani, F. 1998. Effect of Raw Material Quality on Lipids and Flavour Characteristics of Dried Salted Sardines. Thesis. Department of Food Science and Technology. Faculty of Applied Science. The University of New South Wales.

Ariyani, F., Amin, I., Fardiaz, D. dan Budiyanto, S. 2008. Aplikasi ekstrak daun sirih (Piper betle Linn) dalam menghambat oksidasi lemak jambal patin (Pangasius hypophthalmus). Jurnal Pascapanen dan Bioteknologi Kelautan dan Perikanan. 3(2): 157-169.

Ariyani, F., Haryati, S., Wahyuni, M., dan Sugeng Hari Wisudo, S.H. 2009. Penggunaan ekstrak bawang putih (Allium sativum) untuk menghambat kerusakan jambal patin (Pangasius hypophthalmus) selama penyimpanan suhu kamar. Prosiding Seminar Nasional Kelautan V. Dampak Krisis Global terhadap Pembangunan Kelautan dan Perikanan dalam Rangka Peningkatan Kesejahteraan Masyarakat Maritim. Tahun 2009. Universitas Hang Tuah. 23 April 2009. P: II-467 s/d II-473.

Ariyani, F., Murtini, J.T., dan Siregar, T.H. 2010. Penggunaan ekstrak daun jambu biji (Psidium guajava) sebagai pengawet pindang tongkol. Jurnal Pascapanen dan Bioteknologi Kelautan dan Perikanan. 3(2): 139-146.

Aubourg, S.P. 2000. Assessment of antioxidant effectivenes on thermally treated marine lipids by fluorescence detection. Eur Food Res Technol. 211: 310-315.

Chotimarkorn, C., Ohshim, T. and Ushio, H. 2006. Fluorescent image analysis of lipid hydroperoxides in fish muscle with 3-perylene diphenylphosphine. Lipid. 41(3): 295-300.

Davis, L., Goodwin, L., Smith, G. and Hole, M. 1993. Lipid oxidation in salted-dried fish: II. The effect of temperature and light on the rate of oxidation of a fish oil. J. Sci. Food Agric. 62: 355-359.

Ditjen Perikanan Budidaya. 2010. Pedoman Perencanaan Pengembangan Kawasan Perikanan Budidaya (Minapolitan).

Fletcher, B.L., Dillard, C.J. and Tappel, A.L. 1973. Measurement of fluorescent Lipid peroxidation products in biological systems and tissues. Analytical Biochemistry. 52: 1-9.

Hasegawa, K., Endo, Y., and Fujimoto, K. 1992. Oxidative deterioration in dried fish model systems assessed by solid sample fluorescence spectrophotometry. Abstract. J. Food Sci. 57(5): 1123-1126.

Haard, N. and Chism, G.W. 1994. Characteristics of edible plant tissues. In Fennema, O.R. (ed.). Food Chemistry. $3^{\text {rd }}$ Edition. New York. Marcel Dekker Inc. p. 943-1001.

Hui-Yin, C. and Gow-Chin, Y. 2007. Antioxidant activity and free radical-scavenging capacity of extracts from guava (Psidium guajava L.) leaves. Food Chemistry. 101(2): 686-694.

Indrasena, W.M. and Barrow, C.J. 2011. Oxidation and stability of food-grade fish oil : role of antioxidants. In Alasalvar, C., Shahidi, F., Miyashita, K. and Wanasundara, U. (eds.). Handbook of Seafood Quality, Safety and Health Applications. Sussex, U.K. Blackwell Publishing Ltd. p. 317-334.

Kato, S., Post, G.C., Bierbaum, C.M. and Koch, T.H. 2002. Chemical ionization mass spectrometric determination of acrolein in human breast cancer cells. Analytical Biochemistry. 305: 251-259

Ke, P.J. and Ackman, R.G. 1976. Metal-catalysed oxidation in mackerel skin and meat lipids. J. Am. Oil Chem. Soc. 53(10): 636-640

Lubis, Z. 1989. Studies on the Stability of Lipids in Dried Salted Sardines [thesis]. Department of Food Science and Technology, School of Applied Bioscience, Faculty of Applied Science. The University of New South Wales.

Mahyuddin, K. 2010. Panduan Lengkap Agribisnis Patin. Penebar Swadaya. Jakarta-Indonesia. 212 pp.

Mahmoud, E.A.E., Dostálová, J., Lukešová, D. and Dole•al, M. 2009. Oxidative changes of lipids during microwave heating of minced fish flesh in catering. Czech J. Food Sci. 27 Special Issue: S17-S19.

Nasran, S., Murtini, J.T., Rahayu, S., Mahyudin, Hanafi, Sudrajat, Y., Gunawan, B., dan Maryadi. 1995. Laporan Teknis Penelitian Teknologi Proses Fermentasi dan Pengasapan Hasil Perikanan untuk Pengembangan Agroindustri Pedesaan. Balai Penelitian Perikanan Laut, Pusat Penelitian dan Pengembangan Perikanan. Jakarta. $17 \mathrm{pp}$.

Nazemroaya, S., Sahari, M.A., and Rezaei, M. 2011. Identification of fatty acid in mackerel (Scomberomorus commersoni) and shark (Carcharhinus dussumieri) fillets and their changes during six month of frozen storage at $-18^{\circ} \mathrm{C}$. J. Agr. Sci. Tech. 13: 553-566.

Oduor-Odote, P.M and Obiero, M. 2009. Lipid oxidation and organoleptic response during shelf storage of some smoked marine fish in Kenya. African Journal of Food Agriculture Nutrition and Development. 9(3): 887-900.

Pak, C.S. and Bragadottir, M. 2005. Stability and quality of fish oil during typical domestic application. Fisheries Training Programme. Reykjavik, Iceland: The United Nation Univer. 27 pp. 
Pokorny, J., Yanishlieva, N. and Gordon, M. 2001. Antioxidants in Food. Pratical Application. Woodhead Publishing Limited. Cambridge England.

Pirestani, S., Sahari, N.A., and Barzegar, M. 2010. Fatty acids changes during frozen storage in several fish species from South Caspian Sea. J. Agr. Sci. Tech. 12: 321-329.

Qian He, N.V. 2004. Antioxidant power of phytochemicals from Psidium guajava leaf. Journal of Zhejiang University SCIENCE. 5(6): 676-683.

Ramanathan, L. and Das, N.P. 1992. Studies on the control of lipid oxidation in ground fish by some polyphenolic natural products. J. Agric. Food Chem. 40(1): 17-21.

Sádecká, J. and Tóthová, J. 2007. Fluorescence spectroscopy and chemometrics in the food classification " a review. Czech J. Food Sci. 25: 159173.

Shahidi, F. 1998. Assessment of lipid oxidation and offflavor development in meat, meat products and seafoods. Flavour of Meat, Meat Products and Seafoods. $429 \mathrm{pp}$.

Shahidi, F. and Zhong, Y. 2005. Fluorescence products. In Shahidi, F. (ed.). Lipid Oxidation: Measurement Methods. Bailey's Industrial Oil and Fat Products,
Sixth Edition, Six Volume Set. John Wiley \& Sons, Inc. 357-385.

Sivertsen, A., Lauritzsen, K., Veberg, A. and Wold, J.P. 2006. Rapid assessment of storage quality of clifffish from saithe by fluorecence spectroscopy. In Luten, J.B., Jacobsen, C., Bekaert, K., Saebo, A., and Oehlenschlager (eds.). J. Seafood Research from Fish to Dish : Quality, Safety and Processing of Wild and Farmed Fish. Netherlands. Wageningen Academic Publishers. 566 pp.

Stephen, A.O., Akanji, M.A. and Oguntoye, S.A. 2009. Ethanolic leaf extract of Psidium guajava: Phytochemical and trypanocidal activity in rats infected with Trypanosoma brucei brucei. J. Med. Plants Res. 3(5): 420-423.

Tachakittirungrod, S., Okonogi, S. and Chowwanapoonpohn, S. 2007. Study on antioxidant activity of certain plants in Thailand: Mechanism of antioxidant action of guava leaf extract. Food Chemistry. 103(2): 381-388.

Tatum, V. and Chow, C.K. 1992. Effects of processing and storage on fatty acids in edible oils. In Chow, C.K. (ed.). Foods and Their Health Implications. Marcel Dekker, Inc., New York. p. 337-351. 